\title{
Model Pengembangan Kelembagaan Kemitraan dan Pemasaran Temulawak di Kota Semarang ${ }^{1)}$
}

\author{
Ninuk Purnaningsih ${ }^{2)}$
}

Produk biofarmaka, yang salah satunya berasal dari tumbuhan, sangat berpotensi dalam pengembangan Industri Obat Tradisional (IOT) dan kosmetika di Indonesia. Penggunaan tumbuhan oleh IOT dimulai dengan memanfaatkan tumbuhan yang diperoleh dari hutan alam (hasil kegiatan ekstraktif) dan produk budidaya. Sebagai produk budidaya, sumber biofarmaka ini teknik budidayanya belum tertata dengan baik. Fakta ini memberikan peluang besar sekaligus tantangan untuk peningkatan sumbangan produksi dan produk olahan tanaman obat hasil budidaya. Kebutuhan akan biofarmaka untuk industri dalam negeri semakin meningkat dari tahun ke tahun. Pada tahun 2000 mencapai 6.813 ton, meningkat di tahun 2001 menjadi 7.170 ton, dan pada tahun 2002 peningkatan mencapai 8.104 ton. Peningkatan kebutuhan bahan baku ini berjalan seiring dengan meningkatnya jumlah industri jamu, farmasi dan kosmetika. Pada tahun 2000 kebutuhan tanaman temulawak (yang merupakan tanaman rimpang terbesar ke-3 setelah tanaman lempuyang dan jahe) untuk 5 (lima) industri jamu terbesar mencapai 38.600 $\mathrm{kg} / \mathrm{bulan}$ atau $463.200 \mathrm{~kg} /$ tahun. Perkiraan WHO sekitar $14-28 \%$ dari 250 ribu jenis tumbuhan di dunia yang berpotensi untuk dikembangkan menjadi bahan obat tradisional.

Strategi pengembangan agribisnis biofarmaka dapat mengambil bentuk pada pola-pola penumbuhan dan penguatan kelembagaan berbasis pada komunitas lokal/petani, utamanya bagi produk biofarmaka yang telah lazim dibudidayakan oleh masyarakat setempat, seperti temulawak, jahe dan sebagainya. Berbagai pola pengembangan agribisnis biofarmaka dapat dilakukan, umpamanya melalui pola kemitraan (partnership) yang mengintegrasikannya dengan perusahaan jamu skala besar (nasional) atau dengan kelembagaan sosial dan ekonomi lainnya. Peluang demand pasar bahan obat-obatan yang terus terbuka, diiringi dengan semakin banyaknya perusahaan yang masuk ke bidang pengolahan obat-obatan dan kosmetik berbahan baku biofarmaka, memberikan keadaan yang kondusif bagi perusahaan agribisnis biofarmaka atau petani biofarmaka untuk dapat meningkatkan pendapatan rumahtangganya.

\footnotetext{
1) Tulisan ini merupakan sebagian analisis dari Penelitian Model Pengembangan Kemitraan dan Pemasaran Terpadu Komoditas Temulawak di Kota Semarang.

${ }^{2)}$ Staf Pengajar Departemen Sains Komunikasi dan Pengembangan Masyarakat, Fakultas Ekologi Manusia Institut Pertanian Bogor
} 
Kecamatan Tembalang dan Banyumanik merupakan dua kecamatan penghasil Temulawak khususnya dan rimpang umumnya di Kota Semarang. Tulisan ini bertujuan untuk: (1) menganalisis model pemasaran dan kelembagaan dalam memberdayakan petani temulawak yang telah ada di Kota Semarang, (2) mendeskripsikan tahapan kegiatan pengembangan dan pemberdayaan infrastruktur sosial ekonomi penopang kegiatan agribisnis temulawak yang telah ada dan dibutuhkan dalam membangun model pemasaran temulawak di Kota Semarang, dan (3) menganalisis jejaring usaha agribisnis temulawak di tingkat lokal-regional yang ideal dapat dilakukan oleh petani temulawak di Kota Semarang.

Tulisan ini merupakan sebagian analisis yang didasarkan pada data penelitian lapangan tentang Model Kemitraan dan Pemasaran Terpadu Biofarmaka di Kota Semarang Propinsi Jawa Tengah, yang dilakukan pada akhir tahun 2006

\section{TAHAPAN KEGIATAN PENELITIAN}

Kegiatan penelitian yang seharusnya di awali dengan pembentukan kelompok tani yang khusus berusaha dalam produksi tanaman biofarmaka, khususnya temulawak dan empon-empon lainnya, tidak dilaksanakan karena di sentra produksi yang menjadi objek kegiatan (Kecamatan Tembalang) sudah memiliki beberapa kelompok tani yang bergerak di bidang ini. Oleh karena itu, kegiatan ini disubstitusi dengan mempersiapkan kelompok tani yang akan digabungkan dalam Gapoktan dan memperluas objek binaan menjadi pada 2 (dua) kecamatan, yaitu Tembalang dan Banyumanik. Garis besar pelaksanaan aktivitas penelitian adalah sebagai berikut.

Pengumpulan data existing condition, dalam rangka penjajagan untuk pembentukan Gapoktan Temulawak (Gabungan Kelompok Tani) dan appraisal kelayakan (teknologi, ekonomi, dan sosial budaya), dilakukan dengan metoda wawancara bebas dan wawancara mendalam (indepth interview) ke industri, petani, dan pedagang pengumpul serta instansi (Dinas Pertanian Kota Semarang) yang terkait dengan pengembangan komoditas dan produk Temulawak di lokasi penelitian, seperti wawancara ke CV. Kurnia (dengan brand product: Vitaher), ke Kelompok Tani 'Slamet Raya', ke Ibu Tani Slamet, dan sebagainya. Bahkan untuk memperoleh data-data yang lebih kuantitatif yang lebih layak dipercaya juga melakukan pengambilan data dengan cara survey. Survei dilakukan di 2 (dua) desa di Kecamatan Tembalang, yaitu Desa Bulusan dan Desa Kramas dan 2 (dua) desa lainnya, yaitu Gedawang dan Jabungan di Kecamatan Banyumanik.

1. Terhadap data-data, baik primer dan sekunder yang diperoleh dilakukan kajian terutama kondisi awal yang berhubungan dengan masalah usahatani, penerapan teknologi, kelembagaan petani dan pasar yang ada. Penajaman informasi dan kajian dilakukan melalui wawancara yang lebih mendalam dengan berbagai pihak yang memiliki kompetensi dan dalam kegiatan FGD (Focus Group Discussion).

2. Berdasarkan hasil kajian tersebut di atas, maka dilakukan pemilihan desadesa yang akan dilibatkan dalam pembentukan Gabungan Kelompok Tani. Dalam pemilihan desa ini tidak hanya memilih 2 desa seperti yang direncanakan pada proposal kegiatan. Dengan pertimbangan histori, geografi, dan prospek 
pengembangan ke depan, maka dipilih 4 (empat) desa dari 2 (dua) kecamatan (masing-masing dua desa per kecamatan) sebagai awal desa-desa yang kelompok taninya menjadi anggota Gapoktan akan dibina melalui kegiatan ini. Desa-desa yang terpilih adalah Desa Bulusan dan Kramas di Kecamatan Tembalang dan desa Gedawang dan Jabungan di Kecamatan Banyumanik.

1. Untuk menjaring masukan, menggali informasi yang lebih rinci, dan sosialisasi agenda kegiatan agar menumbuhkan kesadaran untuk dapat terlibat dan berperan serta dalam kegiatan ini maka dilakukan kegiatan FGD (Focus Group Discussion) yang melibatkan stakeholders (petani, pedagang pengumpul, Dinas Pertanian dan industri). Kegiatan FGD ini tidak saja untuk bahan kajian dalam penerapan Model Kemitraan aagar lebih aplikatif juga dimaksudkan untuk konfirmasi atas data hasil survey yang telah dilakukan sebelumnya.

2. Penyusunan model pengembangan kelembagaan kemitraan dan pemasaran Temulawak yang lebih aplikatif dilakukan oleh tim melalui diskusi-diskusi baik secara internal maupun dengan pihak Dinas Pertanian Kota Semarang dan Penanggung Jawab kegiatan PKSN dari P2HP Departemen Pertanian Pusat.

\section{HASIL DAN PEMBAHASAN}

\section{Gambaran Umum Budidaya dan Pemasaran Temulawak Di Kota Semarang}

Para petani di Kabupaten/Kota Semarang umumnya menanam temulawak pada bulan Januari/Februari dan panen pada bulan Juli/Agustus. Hasil panen temulawak, berupa rimpang, dibersihkan dari tanah yang menempel dan langsung dijual. Hal ini berarti bahwa secara efektif industri pengolah temulawak hanya menyerap rimpang petani selama 2 (dua) bulan dalam setahun. Petani Temulawak di Kabupaten Semarang menjual hasil usahatani biofarmaka langsung kepada pedagang pengumpul (pengepul) yang umumnya juga menjadi petani. Temulawak yang diangkut ke rumah pedagang pengepul merupakan temulawak yang sudah dibersihkan dari tanah-tanah dan kotoran yang melekat pada umbinya, walaupun tidak melakukan pencucian. Proses penyortiran juga dilakukan oleh pedagang pengepul dengan memotong umbi temulawak yang berukuran kecil dan menempel atau menyatu pada umbi yang berukuran besar. Untuk itu, pedagang pengepul melibatkan dan mempekerjakan beberapa buruh wanita, yang khusus untuk memotong umbi yang kecil, mengiris umbi menjadi 'cekokan' dan 'menampi' kotoran-kotoran kering dari sisa-sisa potongan.

Harga rimpang temulawak milik petani dibeli pleh pedagang pengumpul dengan harga Rp 1200,-/kg hingga Rp 1500,-/kg untuk rimpang yang besar dan Rp $700,-/ \mathrm{kg}$ untuk rimpang yang kecil. Harga rimpang ini baru beberapa waktu yang lalu ada kenaikan, setelah hampir 2 (dua) tahun tanpa penyesuaian harga.

Temulawak dari pedagang pengumpul ini dijual ke industri pengolah khususnya ke CV. Kurnia yang dikenal dengan "brand product"-nya sebagai Vitaher. Namun jaringan kemitraan yang selama ini terjalin belum didukung dengan perangkat legalitas yang kuat (tidak formal dan tanpa kontrak karya), hanya baru sebatas petani yang notabene adalah pedagang pengumpul memasok sejumlah rimpang temulawak dan rimpang dibeli olehVitaher dengan harga yang disepakati bersama. 
Rimpang temulawak dari petani, diproses menjadi simplisia melalui proses sortir-cuci-iris-jemur-packaging. Vitaher mengolah simplisia temulawak menjadi bentuk powder untuk memenuhi permintaan ekspor (dengan machine-made), membuat ramuan bahan baku SPA untuk memenuhi permintaan pasar ekspor dari Frankfurt (Germany) dengan hand-made, membuat beberapa obat tradisional (fitofarmaka) yang berbahan baku temulawak dalam bentuk pil atau kapsul, dan membuat berbagai produk lainnya yang berbahan baku temulawak, seperti pasta gigi, dll.

Petani yang memasok temulawak ke Vitaher bukan sepenuhnya petani yang mengandalkan usahatani temulawak sebagai satu-satunya sumber penghasilan. Banyak diantara mereka ketika tidak menanam bekerja di on farm, sebagai buruh/tukang bangunan dan aparat desa, namun adapula petani yang mengandalkan pertanian padi sebagai matapencaharian utama mereka dan usahatani temulawak sebagai sampingan (off farm).

\section{Profil Petani Temulawak Di Kota Semarang}

Pemilihan responden dilakukan secara sengaja yaitu petani yang menanam temulawak. Informasi petani yang menanam temulawak diperoleh dengan cara snowballing atau informasi bergulir dari informan atau respondenn yang satu kepada responden yang lainnya. Berdasarkan metoda tersebut diambil responden sebanyak 101 orang dengan penyebaran lokasi tempat tinggal.

Lebih dari tujuh puluh lima persen responden berasal dari Kecamatan Tembalang terutama dari Kelurahan Kramas dan Kelurahan Bulusan, yaitu masingmasing sebanyak 40,59 dan 38,61 persen. Berdasarkan keterangan dari informan setempat serta dari Dinas Pertanian Kota Semarang, kedua kelurahan tersebut memang merupakan pusat produksi temulawak di Kota Semarang.

Petani temulawak di Kota Semarang umumnya telah berusia tua. Lebih dari 25 persen petani temulawak telah berusia di atas 65 tahun, bahkan berdasarkan pengakuan responden yang paling tua berumur 85 tahun. Hal tersebut kemungkinan karena budidaya temulawak umumnya telah dilakukan secara turun temurun dan tidak membutuhkan pemeliharaan yang intensif, sehingga umumnya masih dapat dilakukan oleh petani yang berada pada kelas umur di atas 70 tahun. Seperti halnya kecenderungan pada usahatani komoditi tanaman pangan, kaum muda tampaknya tidak begitu tertarik dalam usaha budidaya temulawak. Responden termuda berada pada kelas umur 30-35 tahun dan jumlahnya hanya 1,98 persen. Responden terbanyak berada pada kelas umur 51-55 tahun yaitu sekitar 18,82 persen.

Budidaya temulawak telah lama dilakukan petani di Kota Semarang. Pengetahuan dan keterampilan budidaya temulawak umumnya diperoleh dari orang tua mereka secara turun temurun dan ada pula yang belajar dari tetangganya. Sekitar 75 persen responden telah melakukan kegiatan usahatani lebih dari 20 tahun.

Selain temulawak mereka umumnya menanam jenis tanaman obat lainnya seperti: kunyit, temu giring, temu ireng, temu mangga, kencur, kunyit putih, laos, lempuyang, sereh dan sambiloto. Selain itu mereka juga berusahatani tanaman pangan seperti padi dan palawija (kacang tanah, ketela pohon dan jagung), tanaman buah-buahan seperti pisang, rambutan, mangga, durian dan petei, serta tanaman kayu seperti sengon dan jati. 
Seperti telah dijelaskan sebelumnya bahwa petani temulawak mayoritas berumur di atas 50 tahun bahkan ada yang lebih dari 80 tahun. Pada masa lalu sarana pendidikan umumnya belum menjangkau sampai ke pedesaan sehingga pendidikan tidak menjadi prioritas dalam keluarga. Oleh karena itu, sekitar 37 persen petani temulawak mengaku tidak pernah sekolah. Selain itu sekitar 51,5 persen dari jumlah responden hanya berpendidikan SD namun ada juga petani temulawak yang berpendidikan SMA (6,93 persen)

Usahatani temulawak umumnya bukan merupakan usahatani utama dari responden. Meskipun demikian sekitar 62,38 persen responden memiliki pekerjaan utama sebagai petani. Komoditi yang mereka usahakan selain temulawak adalah tanaman obatan-obatan lainnya yang biasa disebut sebagai empon-empon, tanaman pangan, tanaman buah-buahan dan tanaman berkayu.

Usahatani temulawak tidak membutuhkan pemeliharaan intensif, dimana kegiatan yang paling sibuk hanya pada pengolahan lahan dan penanaman. Setelah itu tidak membutuhkan pemeliharaan yang intensif dan hanya tinggal menunggu panen. Oleh karena itu cukup banyak petani temulawak yang memiliki pekerjaan utama sebagai buruh bangunan (16,83 persen). Petani yang tidak memiliki lahan usahatani khusus umumnya menanam temulawak di pekarangan rumahnya atau menggarap lahan milik orang lain, sehingga buruh tani (10,89 persen) juga dapat melakukan usahatani temulawak. Pekerjaan utama lainnya dari responden adalah buruh, PNS dan pensiunan, wiraswasta, jasa angkutan, pegawai swasta dan pedagang.

Sebagian besar responden memiliki pekerjaan sampingan selain pekerjaan utama mereka. Namun ada sekitar 39,60 persen responden yang tidak memiliki pekerjaan sampingan. Sebagian besar responden (31,68 persen) mengaku pekerjaan sebagai petani merupakan pekerjaan sampingan. Pekerjaan sampingan lainnya adalah buruh bangunan, buruh, peternak, pedagang, makelar tanah, jasa angkutan dan tukang kayu.

\section{Mekanisme Pasar dan Pemasaran Komoditas Temulawak}

Sentra produksi Temulawak di Kota Semarang terpusat pada 4 (empat) kelurahan, yaitu Kelurahan Bulusan dan Kelurahan Kramas (berada dibawah wilayah administratif Kecamatan Tembalang) dan Kelurahan Jabungan dan Kelurahan Gedawang (berada dibawah wilayah administratif Kecamatan Banyumanik). Hasil panen temulawak dominan dijual dalam bentuk rimpang (96\%) dan sisanya dalam bentuk simplisia (4\%). Tahapan pemasaran hasil panen temulawak tersebut akan diuraikan pada alinea berikut.

Beberapa petani di 4 (empat) kelurahan tersebut ada yang menjual rimpang maupun simplisia secara langsung ke pasar tradisional yang ada di sekitar Semarang, misalnya ke pasar lokal, Pasar Pronas, Pasar Johar di pusat kota Semarang, Pasar Bulu, Pasar Randusari, Pasar Karangayu dan Pasar Jati. Jumlah yang dijual langsung ke pasar tersebut umumnya dalam partai kecil karena pasar-pasar tersebut umumnya mau menerima dalam jumlah kecil, berbeda halnya dengan penjualan melalui pedagang pengepul/pengumpul yang biasanya dalam partai besar.

Selain itu, dominan petani di 4 (empat) kelurahan itu menjual rimpang yang ditampung terlebih dahulu oleh pedagang pengepul/pengumpul yang juga tersebar 
pada 4 (empat) kelurahan tersebut diatas. Beberapa pedagang pengepul/pengumpul yang mau menampung hasil panen temulawak petani antara lain adalah Ibu Slamet, Ibu Darsi, Ibu Ngapinah, Ibu Kamsi, Ibu Sudarsih, Ibu Narti, Ibu Yahmi, Ibu Watini dan Bapak Karjan. Selanjutnya dari pedagang pengepul/pengumpul tersebut rimpang/simplisia temulawak itu disalurkan ke pedagang besar antar kota/kabupaten, misalnya Ibu Mewa yang merupakan penyalur dari PT. Raja Agung atau pedagang asal Ponorogo yang selanjutnya dijual ke Surabaya. Selain itu, dari pedagang pengepul/pengumpul tingkat kecamatan rimpang Temulawak dijual ke industri Temulawak (CV. Vitaher) atau LIK (Lingkungan Industri Kecil) yang tersebar di Propinsi Jawa Tengah.

Sejak beberapa tahun terakhir ini, petani yang memasok temulawak-nya ke CV. Vitaher berjumlah sekitar 300 -an orang yang tersebar pada beberapa desa di Kecamatan Tembalang dan Banyumanik, antara lain: Kelurahan Bulusan, Kremes, Jabungan dan Kelurahan Gedawang. Sejumlah petani pemasok tersebut tergabung ke dalam 5 (lima) kelompok tani, yaitu Kelompok Tani Sijambu, Makmur, Sigeblok Asri, Slamet Raya dan Kelompok Tani Usaha Mulia, yang masing-masing kelompok tani tersebut memiliki keanggotaan $25-40$ petani Temulawak. Inisiatif pembentukan kelompok adalah merupakan ide dari Ibu Dewi (pemilik CV. Vitaher), dengan tujuan untuk memudahkan kontinuitas ketersediaan Temulawak dan agar berjalan transfer teknologi budidaya Temulawak organic dari ketua kelompok kepada petani-petani lain yang berminat membudidayakan Temulawak di Semarang. Sejauh ini, pembinaan yang dilakukan oleh Vitaher ke kelompok tani dalam bentuk:

(1) penyuluhan dan aksi tentang pembudidayaan temulawak organik

(2) peningkatan kualitas rimpang melalui mekanisme pengupasan dan pengirisan tipis $\rightarrow$ banyak petani tidak dapat menerapkannya karena keterbatasan air dan karena proses pengirisan adalah sesuatu yang sulit bagi petani (perlu keahlian khusus dan tertentu)

Petani yang memasok Temulawak ke CV.Vitaher bukan sepenuhnya petani yang mengandalkan usahatani Temulawak sebagai satu-satunya sumber penghasilan. Banyak diantara mereka ketika tidak menanam Temulawak di lahannya, bekerja di on farm sebagai buruh/tukang bangunan dan aparat desa, namun adapula petani yang mengandalkan pertanian padi sebagai matapencaharian utama mereka dan usahatani Temulawak sebagai sampingan (off farm).

Selanjutnya rimpang Temulawak dari petani, setelah melalui proses sortircuci-iris-jemur-packaging, yang selanjutnya rimpang dirubah menjadi simplisia, yang selanjutnya dijual kepada industri obat tradisional (IOT) yang tersebar di Jawa Tengah, antara lain ke pabrik jamu Ny. Meneer, pabrik jamu Leo dan pabrik jamu Borobudur. Sistem pembelian IOT tersebut adalah tidak mengikat, tidak continue dan tergantung pada kebutuhan pabrik, dalam arti jika butuh maka akan ada order tetapi jika tidak butuh maka tidak akan membeli ke CV. Vitaher. Sejauh ini belum ada kontrak yang mengikat antara CV. Vitaher dengan para IOT tersebut.

CV. Vitaher ini selain menampung rimpang Temulawak dari para petani Semarang juga melakukan beberapa bentuk diversifikasi usaha, antara lain mengolah simplisia Temulawak menjadi bentuk powder untuk memenuhi permintaan ekspor (dengan machine-made), membuat ramuan bahan baku SPA untuk memenuhi 
permintaan pasar ekspor dari Frankfurt (Germany) dengan hand-made, membuat beberapa obat tradisional (fitofarmaka) yang berbahan baku temulawak dalam bentuk pil atau kapsul, dan membuat berbagai produk lainnya yang berbahan baku temulawak, seperti pasta gigi, kosmetika, dan lain-lain.

\section{PENENTUAN HARGA KOMODITAS TEMULAWAK}

Sama halnya dengan komoditas pertanian lainnya, penentuan harga jual hasil panen komoditas Temulawak sangat ditentukan dan bergantung pada pedagang/tengkulak. Petani selalu diposisikan sebagai pihak yang harus menerima harga yang telah ditentukan (price taker) dan pihak yang tidak mampu memiliki bargaining position terhadap para pedagang/penampung/tengkulak. Selain itu, dari sisi supply demand umumnya tidak ada standar mutu yang jelas dan tidak mengikuti standar yang telah ditetapkan pada GAP (good agricultural processing)/GMP (good manufacturing pocessing) sehingga berdampak pada harga jual rimpang/simplisia Temulawak yang rendah. Oleh karena itu, berapapun rimpang/simplisia Temulawak yang dijual petani selalu ditampung oleh pedagang pengepul/pengumpul namun dengan ada differensiasi harga, jika rimpang besar akan dihargai lebih tinggi daripada rimpang yang kecil. Banyak pula petani yang cenderung tidak mau repot dengan menjual hasil panen Temulawaknya dalam bentuk rimpang basah.

Para petani menjual hasil temulawak dalam bentuk rimpang (basah) yang diperoleh dari hasil pertanian temulawak organic dan ditampung oleh $\mathrm{CV}$. Vitaher dengan harga Rp 900,- per kilogram untuk kualitas yang besar dan baik. Jika petani menjual rimpang basah ke pasar tradisional umumnya dihargai jauh lebih rendah daripada harga jual di CV. Vitaher, yaitu sekitar Rp 500,- hingga Rp 700,- per kilogram. Selain menjual rimpang basah, ada pula petani yang menjual dalam bentuk simplisia, biasanya dihargai mulai dari Rp 1500,- (kualitas jelek) hingga Rp 4500,- untuk kualitas yang bagus.

Sistem pembayaran yang disepakati antara petani dan pengepul/penampung/tengkulak maupun dengan industri biofarmaka melalui beberapa mekanisme pembayaran, yaitu:

(1) Sistem pembayaran kepada petani dilakukan dengan mekanisme sistem tunda, yaitu petani akan dibayar apabila simplisia telah dibayar oleh perusahaan obat yang membelinya. Namun demikian, dalam hal ini CV.Vitaher memiliki komitmen yang cukup tinggi untuk memberdayakan dan memberikan kepastian dan jaminan pasar kepada petani temulawak dengan membeli rimpang temulawak dalam jumlah berapapun asalkan sesuai dengan keinginan dan kualitas yang telah ditetapkan oleh CV. Vitaher, dengan tanpa ataupun sudah ada pasar (industri obat tradisional) yang membeli simplisia Temulawaknya. Sehingga yang terjadi saat ini adalah adanya penimbunan (stok) simplisia yang memenuhi gudangnya, yang kadangkala stok simplisia temulawak tersebut dapat berbulan-bulan bahkan bertahun-tahun berada di gudang penyimpanannya (pabrik).

(2) Mekanisme pembayaran yang serupa dengan 'sistem ijon' dimana pedagang pengepul/tengkulak memberikan pinjaman uang dan bibit bagi petani yang 
membutuhkannya. Pembayaran hutang tersebut akan dilakukan jika Temulawak sudah siap untuk dipanen. Dalam hal ini ada keengganan petani untuk meminjam uang ke lembaga peminjaman resmi karena adanya persyaratan jaminan. Pada kondisi ekonomi terdesak karena harus memenuhi kebutuhan hidup sehari-hari, tidak sedikit petani yang menjual hasil panen Temulawak sebelum waktunya kepada pedagang pengepul/tengkulak, atau bahkan menjual langsung di lahan/kebun dengan harga rimpang yang sangat murah.

(3) Sistem pembayaran tunai juga dilakukan oleh pedagang pengepul/tengkulak, sejauh kualitas Temulawak yang diinginkan oleh industri terpenuhi. Alternatif ini dilakukan pedagang pengepul/tengkulak dengan dasar pertimbangan petani membutuhkan modal untuk menanam kembali bibit Temulawaknya.

\section{KONDISI KELEMBAGAAN KEMITRAAN DAN PEMASARAN TEMULAWAK}

Kondisi kelembagaan pemasaran temulawak yang ada saat ini seperti terlihat pada Gambar 1.

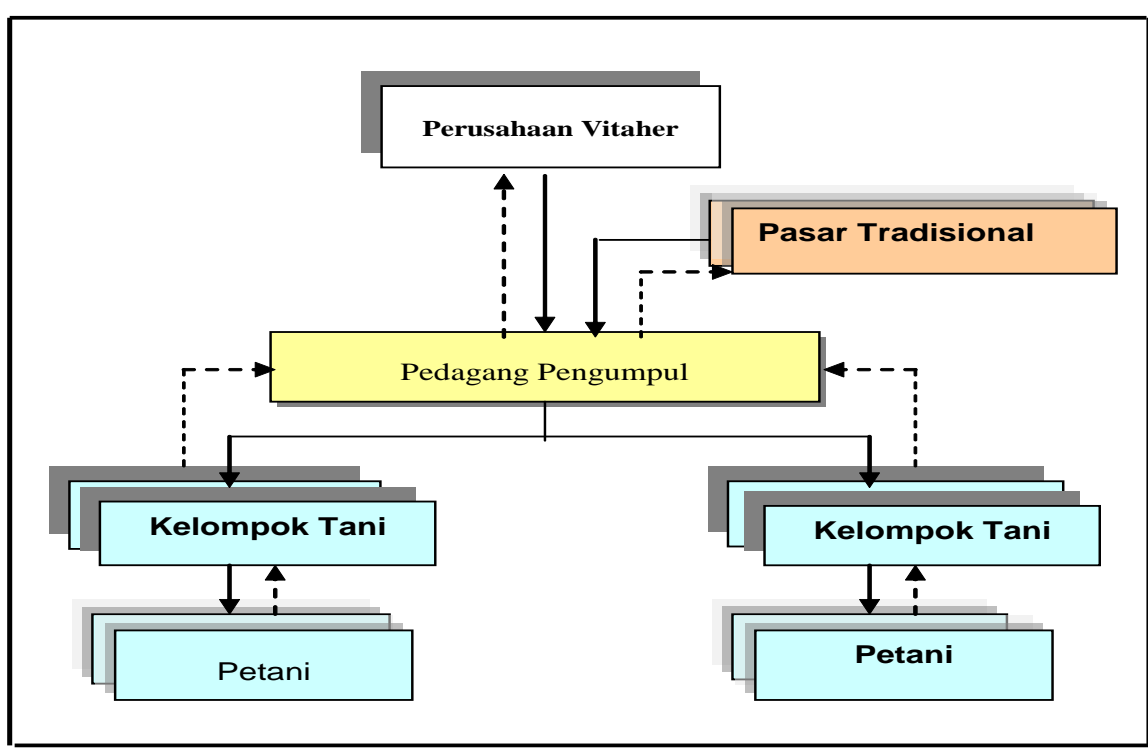

Keterangan:

$\rightarrow$ Arus uang, dan informasi tentang jenis dan mutu produk vano dihutuhkan

Gambar 1 terlihat bahwa posisi pedagang pengumpul menjadi posisi sentral dalam kelembagaan pemasaran. Pedagang pengumpul merupakan penghubung antara petani dengan pesar tradisional dan perusahaan Vitaher sebagai pembeli utama produk temulawak petani.

Tingkat kemitraan yang dijalin antar stakeholder dalam budidaya dan pemasaran temulawak dapat dijelaskan pada bagian berikut. Petani tergabung dalam 
kelompok-kelompok tani yang ada di setiap desa. Kelompok tani sebagai wadah untuk memudahkan proses komunikasi antar berbagai pihak dengan petani temulawak, misalnya dinas pertanian, pedagang pengumpul, perusahaan pengolah temulawak.

Dapat dikemukakan bahwa tingkat kemitraan antara petani temulawak, pedagang pengumpul dan perusahaan telah mencapai skor 630 dari 950 skor maksimal. Dari dua aspek analisis, yaitu aspek proses manajemen kemitraan dan aspek manfaat, ternyata skor proses manajemen masih 260 dari 500 skor maksimal sedangkan aspek manfaat mencapai skor 395 dari 450 skor maksimal. Dengan demikian dapat disimpulkan bahwa kemitraan yang terjalin sudah memberikan manfaat yang baik bagi petani, baik secara ekonomi, teknis dan sosial, namun belum diorganisir dengan baik sehingga perlu perbaikan dari aspek manajemen proses kemitraannya.

\begin{tabular}{|c|c|c|c|c|}
\hline No. & Aspek & Kondisi Saat ini & Skor & $\begin{array}{c}\text { Skor } \\
\text { Maksimal }\end{array}$ \\
\hline \multicolumn{3}{|c|}{ I. Proses Manajemen Kemitraan } & 260 & 500 \\
\hline \multirow[t]{3}{*}{ A. } & \multicolumn{2}{|c|}{ Perencanaan } & 130 & 150 \\
\hline & $\begin{array}{l}\text { A.1.Perencanaan } \\
\text { Kemitraan }\end{array}$ & $\begin{array}{l}\text { Penyusunan rencana dilakukan oleh } \\
\text { perusahaan mitra dan kelompok mitra }\end{array}$ & 100 & 100 \\
\hline & $\begin{array}{l}\text { A.2.Kelangkapan } \\
\text { Perencanaan }\end{array}$ & $\begin{array}{l}\text { Lingkup perencanaan meliputi aspek } \\
\text { pemasaran dan pembinaan teknologi }\end{array}$ & 30 & 50 \\
\hline \multirow[t]{8}{*}{ B. } & \multicolumn{2}{|l|}{ Pengorganisasian } & 130 & 350 \\
\hline & B.1. Bidang Khusus & $\begin{array}{l}\text { Tidak ada bidang khusus/unit yang } \\
\text { menangani kegiatan kemitraan }\end{array}$ & 0 & 25 \\
\hline & $\begin{array}{l}\text { B.2.Kontrak } \\
\text { Kerjasama }\end{array}$ & $\begin{array}{l}\text { Terdapat kontrak kerjasama secara } \\
\text { lisan }\end{array}$ & 10 & 25 \\
\hline & & $\begin{array}{l}\text { Isi kesepakatan kerjasama hanya } \\
\text { menyangkut kesanggupan membeli } \\
\text { produk, tetapi tidak ada kesepakatan } \\
\text { tentang jumlah, harga, dan waktu } \\
\text { pembayaran }\end{array}$ & 0 & 50 \\
\hline & & $\begin{array}{l}\text { Bentuk kerjasama sederhana, tidak } \\
\text { memuat ketentuan hak dan kewajiban } \\
\text { yang jelas, tetapi jangka panjang }\end{array}$ & 15 & 50 \\
\hline & $\begin{array}{l}\text { B.3. Pelaksanaan dan } \\
\text { efektivitas kerjasama }\end{array}$ & $\begin{array}{l}\text { Pelaksanaan dilakukan sesuai } \\
\text { kesepakatan, tetapi tidak dilakukan } \\
\text { secara transparan }\end{array}$ & 30 & 50 \\
\hline & & $\begin{array}{l}\text { Efektivitas: } \\
\text { 1. Kejelasan Peranan } \\
\text { Ada kejelasan peran masing- } \\
\text { masing pihak: petani sebagai } \\
\text { penghasil produk, pedagang } \\
\text { pengumpul sebagai penampung } \\
\text { hasil petani, perusahaan sebagai } \\
\text { pembeli. }\end{array}$ & 25 & 25 \\
\hline & & $\begin{array}{l}\text { 2. Kontinyuitas suplai } \\
\text { Ada kontinyuitas suplai dari } \\
\text { petani ke perusahaan }\end{array}$ & 25 & 25 \\
\hline
\end{tabular}




\begin{tabular}{|c|c|c|c|c|}
\hline & & $\begin{array}{l}\text { 3. Kualitas suplai } \\
\text { Produk yang dijual memenuhi } \\
\text { kualitas standar yang ditetapkan }\end{array}$ & 25 & 25 \\
\hline & & $\begin{array}{l}\text { 4. Sistem pembayaran } \\
\text { Tidak ada kesepakatan tentang } \\
\text { sistem pembayaran }\end{array}$ & 0 & 25 \\
\hline & & $\begin{array}{l}\text { 5. Cara Pembayaran } \\
\text { Rata-rata pembayaran dilakukan } \\
\text { labih dari } 4 \text { minggu }\end{array}$ & 0 & 25 \\
\hline & & $\begin{array}{l}\text { 6. Penentuan harga } \\
\text { Harga ditentukan oleh pihak } \\
\text { perusahaan atau sesuai harga } \\
\text { yang berlaku di pasar }\end{array}$ & 0 & 25 \\
\hline \multicolumn{3}{|c|}{ II. Manfaat Kemitraan } & 370 & 450 \\
\hline \multirow[t]{5}{*}{ A. } & \multicolumn{2}{|c|}{ Manfaat secara Ekonomi } & 170 & 250 \\
\hline & A.1.Pendapatan & $\begin{array}{l}\text { Pendapatan petani sebagian besar sama } \\
\text { dibanding sebelum bermitra }\end{array}$ & 50 & 100 \\
\hline & A.2. Harga & $\begin{array}{l}\text { Harga yang diterima sebagian besar } \\
\text { petani lebih tinggi dengan harga pasar }\end{array}$ & 50 & 50 \\
\hline & A.3. Produktivitas & $\begin{array}{l}\text { Produktivitas melalui kemitraan lebih } \\
\text { tinggi dibanding jika tidak melalui } \\
\text { kemitraan }\end{array}$ & 50 & 50 \\
\hline & A.4.Resiko Usaha & $\begin{array}{l}\text { Jika ada masalah resiko ditanggung } \\
\text { sendiri oleh petani }\end{array}$ & 20 & 50 \\
\hline \multirow[t]{3}{*}{ B. } & \multicolumn{2}{|l|}{ Manfaat Teknis } & 100 & 100 \\
\hline & B.1. Mutu & $\begin{array}{l}\text { Mutu produk yang dihasilkan melalui } \\
\text { kemitraan lebih baik daripada tidak } \\
\text { melalui kemitraan }\end{array}$ & 50 & 50 \\
\hline & $\begin{array}{l}\text { B.2. Penguasaan } \\
\text { teknologi }\end{array}$ & $\begin{array}{l}\text { Pengetahuan dan ketrampilan petani } \\
\text { tentang produk yang dimitrakan } \\
\text { meningkat dibanding sebelum bermitra }\end{array}$ & 50 & 50 \\
\hline \multirow[t]{4}{*}{ C. } & Manfaat Sosial & & 100 & 100 \\
\hline & $\begin{array}{lr}\text { C.1. } & \text { Keingingan } \\
\text { untuk melanjutkan } \\
\text { kerjasama }\end{array}$ & $\begin{array}{l}\text { Baik perusahaan maupun petani } \\
\text { berkeinginan untuk melanjutkan } \\
\text { kerjasama }\end{array}$ & 50 & 50 \\
\hline & $\begin{array}{l}\text { C.2. Kelestarian } \\
\text { lingkungan }\end{array}$ & $\begin{array}{l}\text { Konservasi tanah, dan lingkungan } \\
\text { pertanian terjaga dengan menerapan } \\
\text { pola kemitraan }\end{array}$ & 50 & 50 \\
\hline & Skor Total & & 630 & 950 \\
\hline
\end{tabular}

\section{RANCANGAN PENGEMBANGAN MODEL KEMITRAAN DAN PEMASARAN}

Dengan mengevaluasi kondisi saat ini tentang kelembagaan pemasaran tingkat kemitraan antar stakehoder, maka rancangan pengembangan model kemitraan dan pemasaran yang diusulkan adalah sebagai berikut:

1. Pedagang pengumpul yang juga berstatus sebagai petani bergabung dengan kelompok-kelompok tani membentuk Organisasi Gabungan Tani (Gapoktan). Gapoktan ini berperan sebagai organisasi ekonomi sekaligus 
bersifat sosial yang melakukan kegiatan pemasaran temulawak sekaligus wadah pembinaan petani dari aspek teknologi, manajemen usaha, kepemimpinan maupun kewirausahaan.

2. Gapoktan dalam melakukan fungsinya sebagai lembaga pemasaran temulawak berupaya untuk memperkuat posisi petani dalam hubungan kemitraan dengan perusahaan maupun pasar lainnya baik pasar tradisional maupun pasar khusus.

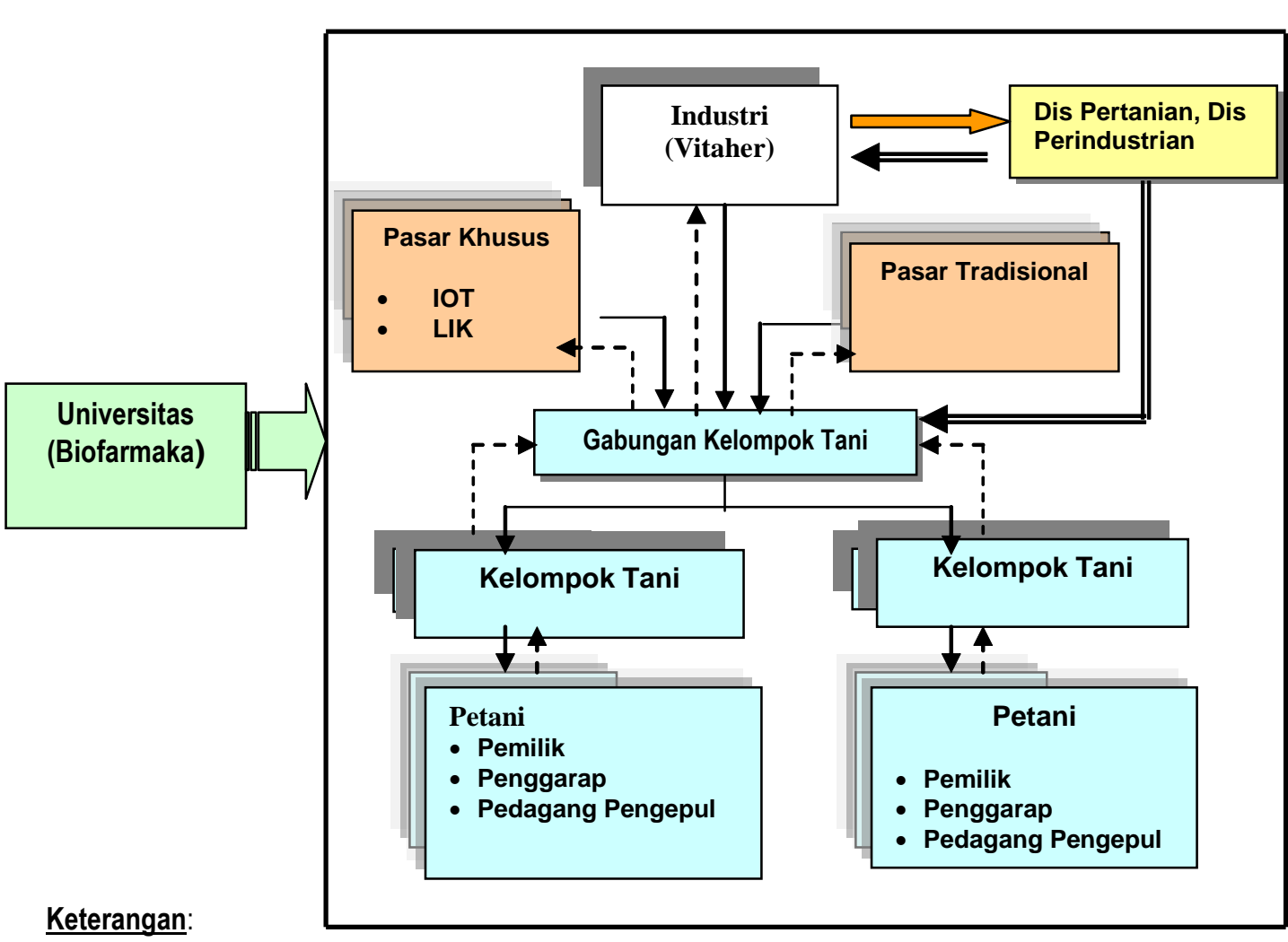

$\rightarrow$ Arus uang, dan informasi tentang jenis dan mutu produk yang dibutuhkan.

$\rightarrow$ Arus barang

Pembinaan dan pengawasan

\section{UJI COBA PENERAPAN MODEL APLIKATIF.}

Pada tahap ini dilakukan uji coba model pengembangan kemitraan dan pemasaran. Sesuai dengan temuan di lapangan dan model yang dibangun maka tahap-tahap uji coba model adalah sebagai berikut:

i. Secara bertahap Gapoktan telah berhasil didorong membuat kelengkapan organisasi (dengan bantuan pendamping), yaitu AD/ART. 
Pada tahap berikutnya Gapoktan didampingi untuk merancang kesepakatan antara petani, pedagang pengumpul dan pengusaha tentang mutu produk temulawak, harga, jumlah yang diperlukan, cara pembayaran, secara bertahap melalui proses dialog dalam pertemuanpertemuan kelompok, diharapkan akan dilakukan sampai akhir tahun 2007.

ii. Bantuan Modal usaha direncanakan akan diberikan dalam bentuk kredit usaha. Modal akan dititipkan di Bank Pasar yang ditunjuk oleh Dinas Pertanian. Pencairan dana dilakukan dengan kesepakatan Dinas dan Gapoktan (dengan rekening atas nama Ketua Gapoktan) berdasarkan pertimbangan jenis peruntukkannya (misalnya untuk modal pembelian ke petani, pengadaan alat/mesin pengolah, pelatihan ketrampilan anggota kelompok, dll) dan rencana pengembalian yang realistis. Akan dibuat kesepakatan tentang mekanisme menyaluran bantuan modal antara Dinas Pertanian, Gapoktan, dan Bank Pasar. Bantuan modal diharapkan dapat dimafaatkan secara bergiliran oleh anggota dan berkembang menjadi lebih besar, yang nantinya akan menjadi aset Gapoktan.

iii. Kepengurusan disusun berdasarkan proses pemilihan dan kesepakatan anggota. Sementara ini kepengurusan Gapoktan Temu Jaya Makmur terdiri dari Ketua, Wakil Ketua, Sekretaris 1, Sekretaris 2, dan Bendahara. Kepengurusan ini dapat berkembang menurut kebutuhan.

iv. Organisasi Gapoktan berfungsi sebagai wadah pembinaan petani. Pelatihan-pelatihan dilakukan oleh Dinas Pertanian dan Univesitas secara bersama-sama untuk memperkuat kelembagaan dan organisasi Gapoktan.

\section{REKOMENDASI}

Secara keseluruhan kegiatan yang dilaksanakan pada tahun 2006 sesuai dengan yang telah direncanakan. Saat ini telah dimiliki data-data yang dapat dijadikan acuan untuk menentukan langkah dan kebijakan selanjutnya. Dengan melihat hasil tersebut akan sangat disayangkan jika kegiatan ini tidak dilanjutkan karena hasil ini baru merupakan awal dari banyak tahap yang harus dilakukan untuk menciptakan model pengembangan komoditas pertanian, khususnya biofarmaka.

Rencana kegiatan lanjutan mencakup penguatan kelembagaan gapoktan, penguatan pemasaran, dan peningkatan jaminan produksi (kualitas, kuantitas, dan kontinuitas). Penguatan kelembagaan Gapoktan meliputi: (1) Menyiapkan data base anggota Gapoktan dan pengadministrasian setiap kegiatan dalam kelompok, (2) memperkuat interaksi antar anggota, sesama pengurus, dan anggota-pengurus, (3) Penjajagan pembentukan unit-unit kegiatan dalam Gapoktan yang mengkoordinir kegiatan petani produsen, petani yang mengolah hasil, dan petani yang juga memasarkan (misalnya unit produksi, unit pengolahan, dan unit pemasaran), (4) Penjajagan untuk perluasan keanggotaan Gapoktan 
Penguatan Pemasaran meliputi: (1) mengembangkan sistem informasi pasar (harga, jenis produk, mutu produk yang dibutuhkan konsumen), (2) mempertahankan dan memantapkan pasar yang ada, (3) promosi dalam rangka menjaring pasar yang baru baik pasar lokal maupun pasar regional. Peningkatan jaminan mutu produk, meliputi: (1) peningkatan produktivitas melalui penambahan dosis pupuk organik, (2) perluasan areal tanam untuk memenuhi kuantitas dan kontinuitas supply, (3) penjajagan penerapan konsep TQM dengan cara melakukan pendokumentasian prosedur operasional standar (SOP) untuk GAP, dan GMP serta dilengkapi dengan sertifikasi system jaminan mutu, (4) pelatihan teknologi penanganan pasca panen produk biofarmaka

\section{DAFTAR PUSTAKA}

Departemen Pertanian. 2003. Pedoman Kemitraan Usaha Agribisnis. Direktorat Pengembangan Usaha.

Rakhmat, Jalaludin. 2001. Psikologi Komunikasi. PT Remaja Rosdakarya. Bandung.

Rogers, E. M. 1995. Diffusion of innovations. Free Press. 4th ed. New York.

Sitorus, Edward. 1994. Makalah Pembahas dalam PIR Perkebunan. Kemitraan Usaha Besar dengan Petani dalam Agribisnis Perkebunan. hal 95103. Yayasan Agrimedia. Jakarta

Soekartawi, 1988. Prinsip Dasar Komunikasi Pertanian. UI Press. Jakarta

Suwarsono dan A.Y. So, 2000. Perubahan Sosial dan Pembangunan. LP3ES. Jakarta

Warsidi . 2003. Sikap terhadap pola kemitraan : Agribisnis Sistem Bagi Hasil dalam Argrimedia (bulan Maret 2003) Direktorat Jendral BPPHP Bina Pengolahan dan Pemasaran Hasil Pertanian.

Yayasan Agrimedia, 1994. Pir Perkebunan. Kemitraan Usaha Besar dengan

Petani dalam Agribisnis Perkebunan. Prosiding Seminar. Jakarta. 